\title{
An Appraisal of the Queensland Flora Survey Guidelines for Protected Plants, Through a Survey of Ipomoea antonschmidii, a Near Threatened Plant of the Northwest Highlands Bioregion
}

\author{
Paul R. Williams ${ }^{1}$ and Bree C. Clouten ${ }^{2}$
}

\begin{abstract}
The Flora Survey Guidelines for Protected Plants are the basis for pre-clearing assessments of Threatened or Near Threatened flora listed under the Queensland Nature Conservation Act 1992. They require targeted searches for listed plants in designated 'high risk areas'. High risk areas are based on a $2 \mathrm{~km}$ radius of a herbarium specimen collection site or a vetted sighting record, with extensions to the $2 \mathrm{~km}$ radius using habitat modelling for some species. High risk areas only cover approximately $2.1 \%$ of Queensland, encompassing a higher proportion of South East Queensland and the Wet Tropics compared with other bioregions. This paper describes a survey method interpreting the Queensland Flora Survey Guidelines, which was used to evaluate Ipomoea antonschmidii, a Near Threatened plant of the Northwest Highlands. We found the timed meander survey method described in the Guidelines provided a useful approach for detecting I. antonschmidii. However, high risk areas do not adequately cover I. antonschmidii, as $84 \%$ of the locations where it was detected in 2011, prior to the amended legislation, are currently outside any high risk area. It is important for botanists and ecologists to be aware of the need for replicating specimen and sightings data over the scale of only a kilometre to improve high risk area maps across the state. Further assessment is required to test and refine modelled habitats of rare flora that contribute to high risk areas. Suggestions of interpretation and refinements of the Guidelines are provided, including the reinstatement of suitable non remnant areas into high risk areas, and a pathway for emerging plant ecologists to become suitably qualified to lead protected plant surveys.
\end{abstract}

Keywords: threatened flora, protected plants, Ipomoea antonschmidii, flora survey guidelines, Queensland Nature Conservation Act

${ }^{1}$ Vegetation Management Science, PO Box 32, Malanda, QLD 4885, Australia (paul@vegetationscience.com.au)

${ }^{2}$ Department of Resources, PO Box 5318, Townsville, QLD 4810, Australia

Williams, P.R., \& Clouten, B. C. (2021). An appraisal of the Queensland Flora Survey Guidelines for Protected Plants, through a survey of Ipomoea antonschmidii, a Near Threatened plant of the Northwest Highlands bioregion. Proceedings of The Royal Society of Queensland, 129, X-Xx. https://doi.org/10.53060/prsq.2021.5

\section{Introduction}

Flora Survey Guidelines for Protected Plants

Of Queensland's 8636 native vascular plant species, 942 (10.9\%) have an Extinct in the Wild, Threatened (Critically Endangered, Endangered or Vulnerable) or Near Threatened status under the Queensland Nature Conservation Act 1992 (NCA; Brown \& Bostock,
2020). A further 20 species, such as Eucalyptus raveretiana, have a common NCA status and are not covered by the Flora Survey Guidelines discussed in this paper, but are listed as either Endangered or Vulnerable under the Federal Environmental Protection and Biodiversity Conservation Act 1999 (EPBCA).

This work is licensed under a Creative Commons Attribution-NonCommercial-NoDerivatives 4.0 International Licence. Individual articles may be copied or downloaded for private, scholarly and not-for-profit use. Quotations may be extracted provided that the author and The Royal Society of Queensland are acknowledged. Queries regarding republication of papers, or parts of papers such as figures and photographs, should be addressed to the Secretary of The Royal Society of Queensland (rsocqld@gmail.com). 
Determining the locations of Threatened or Near Threatened flora is a fundamental aspect for species conservation, and designing an effective method of survey requires consideration of complex factors (Keith, 2000). The NCA provides legal protection to listed fauna and flora across the state. Amendments to the NCA in 2014 introduced guidelines on how and where to survey for the presence of rare flora, which have been updated as Nature Conservation (Plants) Regulation 2020 Protected Plants Assessment Guidelines (Queensland Government, 2020a).

The Flora Survey Guidelines for Protected Plants (Queensland Government, 2020b - here after referred to as the "Guidelines") require targeted surveys for Threatened or Near Threatened plants, where proposed disturbances fall within a "high risk area". A high risk area is defined under Section 132 of the Nature Conservation (Plants) Regulation 2020 (Queensland Government, 2020a):

A high risk area is an area -

(a) in which threatened plants or near threatened plants are present or are likely to be present; and

(b) shown as a high risk area on the flora survey trigger map.

In 2014, these high risk areas simply covered a $2 \mathrm{~km}$ radius of the collection location of a herbarium-stored specimen, or a vetted sighting record on the WildNet database, of a Threatened or Near Threatened plant. WildNet is the Queensland government's database of species records, including herbarium samples and sightings. In 2019, changes to the delineation of high risk areas were made in Version 7.1 of the Guidelines. These changes removed high risk areas from within protected areas (e.g. national parks) and most nonremnant vegetation, excluding category $\mathrm{A}$ areas and category $\mathrm{C}$ (high value regrowth) areas, as defined in the Queensland Vegetation Management Act 1999. In some instances, the high risk areas were expanded beyond a $2 \mathrm{~km}$ radius of a record, based on modelled potential habitat of a Threatened or Near Threatened plant. Combined, these revisions caused an overall decrease in the high risk area across the state from $56,156 \mathrm{~km}^{2}$ in Version 6 , to $36,952 \mathrm{~km}^{2}$ in Version 7.1 - a one-third reduction.

Under the NCA, a survey for Threatened or Near Threatened plants in advance of a disturbance (e.g. land clearing) is only required within high risk areas. If a proposed activity is outside a high risk area, there is no need for a survey, and a permit or exemption under the NCA is only required if the proponent is already aware of, or becomes aware of, a Threatened or Near Threatened plant growing within $100 \mathrm{~m}$ of a planned disturbance (Queensland Government, 2020b: Section 47C).

This means surveys of Threatened or Near Threatened plants in advance of impacts are confined to high risk areas that are largely based on a $2 \mathrm{~km}$ radius of an existing herbarium collection or high-quality sighting record. This raises the question of what proportion of Threatened or Near Threatened plant populations grow outside currently mapped high risk areas. That is, do we currently know enough about rare flora distributions in Queensland to focus pre-disturbance surveys on a $2 \mathrm{~km}$ radius of an existing herbarium sample or sighting record?

\section{Ipomoea antonschmidii}

Ipomoea antonschmidii R.W. Johnson (Convolvulaceae) is a trailing vine with large, alternate, hairy leaves (Johnson, 1986). It has large pink- to mauvecoloured flowers (Figure 1) that are open during the day, closing in the afternoon. The seeds are found inside dry capsules (Figure 2).

Australasian Virtual Herbarium data indicate I. antonschmidii has been collected in 20 locations from north of Mt Isa in North West Queensland to the Northern Territory - Western Australian border (AVH 2021). Seventeen of the 20 collections are from the Northwest Highlands bioregion of Queensland (duplicates of some individual collections are held in multiple herbaria). Plants have been recorded flowering between January and June. Ipomoea antonschmidii has a Near Threatened status under the NCA but is not listed federally under the EPBCA.

There has yet to be a published methodology interpreting the Guidelines, or an assessment of their effectiveness in finding Threatened or Near Threatened flora. Ecological information on I. antonschmidii is also limited. This paper uses data collected on I. antonschmidii before and after the establishment of the Guidelines, to evaluate aspects of its survey requirements and to document ecological aspects of this rare vine. It describes a survey method based on an interpretation of the Guidelines. 


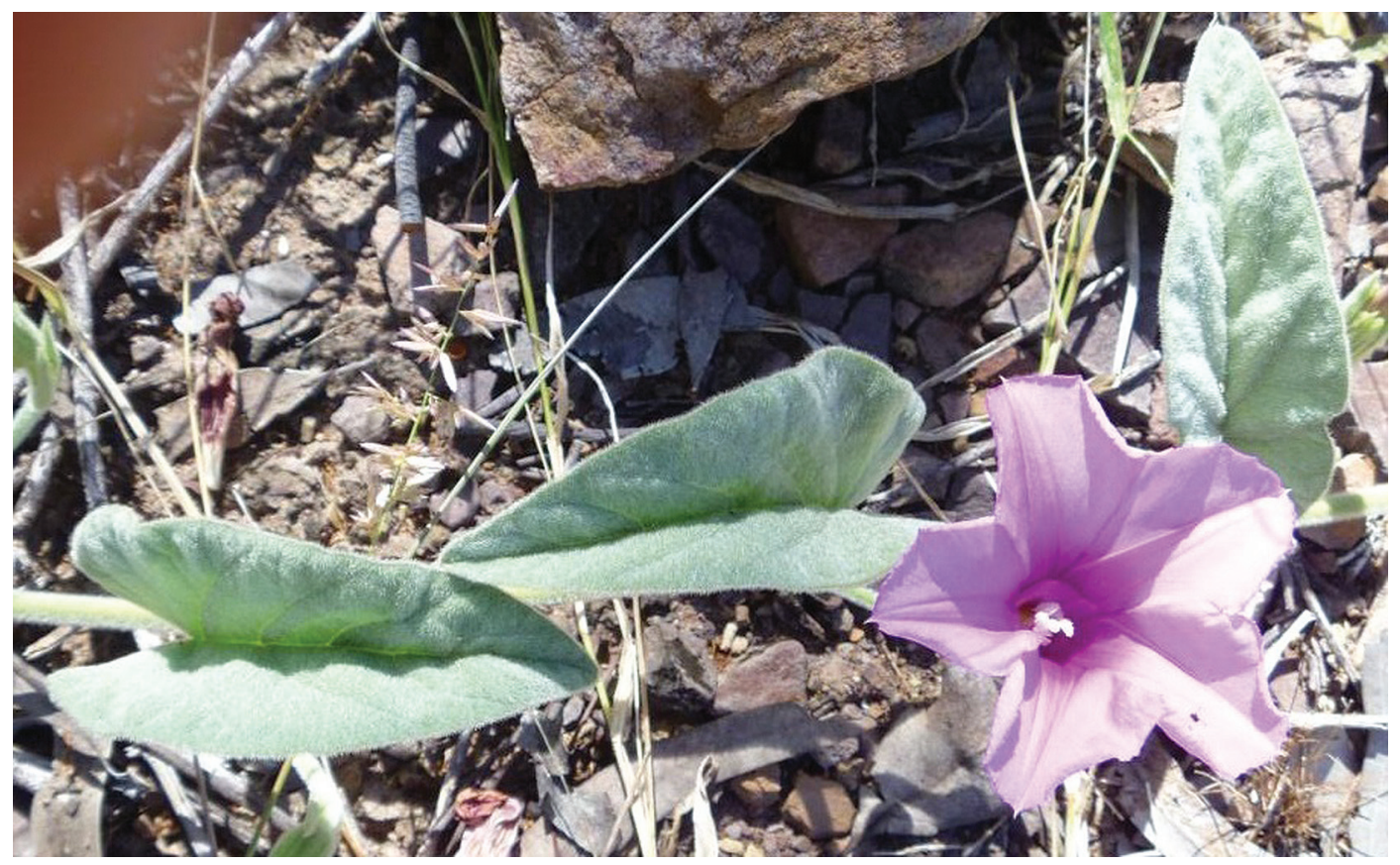

FIGURE 1. Ipomoea antonschmidii in flower, April 2011.

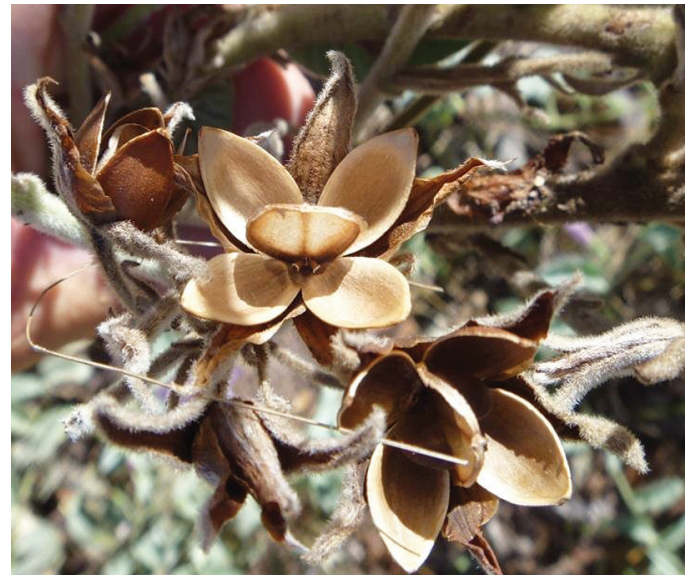

FIGURE 2. Ipomoea antonschmidii capsules, April 2011.

\section{Methods}

The extent of high risk areas was calculated for each of the 13 Queensland bioregions defined in Neldner et al. (2019) to assess the distribution of high risk areas across the state, using the $\operatorname{ArcMap}^{\circledR}$ Version 9.3 geographical mapping program (ESRI, 2009).
In April 2011, prior to the development of high risk areas and the Guidelines, I. antonschmidii plants were observed at 37 locations spanning approximately $100 \mathrm{~km}^{2}$ at a location $>100 \mathrm{~km}$ north of Mt Isa, in the Northwest Highlands bioregion (the exact location has been withheld out of respect for the privacy of the property owner). These 37 separate locations were recorded during an environmental assessment while walking across the landscape to document regional ecosystems and species composition. The I. antonschmidii plants seen in 2011 are represented in the Queensland Herbarium by a single voucher specimen (collection P. R. Williams 1905 + J. Stibbard, Queensland Herbarium reference BRI AQ0834094). At the time, a single voucher combined with additional geographical data for all sighting locations, submitted as part of an environmental impact assessment, was deemed sufficient documentation of the species extent across the area.

In mid-October 2017, subsequent to the development of the Guidelines, work was proposed within a $2 \mathrm{~km}$ radius of the voucher specimen collection site. Following the 2014 protected plant legislation, this had become a high risk area and 
a protected plant survey was undertaken following the Guidelines (Queensland Government, 2020b). The Guidelines require a survey of the disturbance footprint, plus a $100 \mathrm{~m}$ buffer surrounding the proposed disturbance, where it falls within a high risk area. This is called the clearing impact area.

Under the Guidelines, the flora survey must follow either a timed meander method, where the clearing impact area is divided into habitats with 30-minute surveys undertaken in each habitat; or a systematic transect search where large areas are divided into 10 ha blocks and each block is surveyed as an individual unit; or an alternate method that has prior approval from the chief executive.

The timed meander is the most commonly used flora survey method and was used in this study. The Guidelines require at least one 30-minute meander in each habitat of $<2$ ha that falls within a high risk area, two meanders in each habitat of 2 to $10 \mathrm{ha}$, four meanders for 10 to $100 \mathrm{ha}$, and six meanders for $>100$ ha (Queensland Government, 2020b).

The initial step of the survey was a groundtruthed assessment of the distribution of habitats across the survey area. We determined the extent of each individual regional ecosystem, which we used to define separate habitats, although the Guidelines allow a broader view of a habitat, which can combine similar regional ecosystems. The area covered by each habitat was calculated to determine the required number and location of meanders. A survey for Threatened or Near Threatened plants was undertaken using seventeen 30-minute meanders, across seven regional ecosystems spanning 62 ha. A search for protected plants was also undertaken in a small, highly modified non-remnant cleared area (although not using the timed meander survey method).

The timed meander survey method followed the Guidelines (Queensland Government, 2020b). At the start of each meander, a brief general vegetation description was recorded, including the dominant species. A full plant species list was not recorded for each meander. The search for plants was made while walking slowly, in a meandering pattern to cover a broad area. Approximately every 5 minutes, a geographic coordinate was recorded (i.e. a GPS waypoint) which, combined with the meander track log, documented the pattern and location of the meander.
The meander was complete when no Threatened or Near Threatened plant species were seen within a 30-minute period. If a Threatened or Near Threatened plant was observed (in this case I. antonschmidii), the timer was paused to document details about the plants, including abundance. Plant locations were recorded with a GPS coordinate. All individual I. antonschmidii plants in each location were counted, as numbers were sufficiently low and individual plants were easily distinguished. If the plants were too numerous to count, or differentiating individuals was difficult, such as for a grass, an estimate of their abundance would have been made by surveying a CORVEGstyle transect, described by Neldner et al. (2019). Where the landowner provides consent, a plant sample should be collected and submitted to the Queensland Herbarium for confirmation of identification and as a voucher.

Once intercepted individuals of $I$. antonschmidii were documented, the meander was continued from the outer boundary of the observed I. antonschmidii plants. The timer was continued from the point at which it had been paused until 30 minutes had elapsed from the start of the timed meander, without further observations of I. antonschmidii or any other Threatened or Near Threatened plant.

Seven of the 37 I. antonschmidii separate locations observed in 2011 were re-surveyed to assess the persistence of the plants. These seven locations were chosen because they were close to the protected plant survey area and were easily accessed.

\section{Results}

Overall, 2.1\% of Queensland is regulated under the NCA through high risk area mapping (Table 1; Figure 3). This does not represent buffers around all NCA listed Threatened or Near Threatened plant collections because those within the protected area estate or areas mapped as category X (representing non-remnant regional ecosystems or areas that have been 'locked in' as category X areas, through a Property Map of Assessable Vegetation) on the Queensland Government regulated vegetation management map, are no longer within the scope of the high risk area mapping.

The number of Threatened and Near Threatened plants and the coverage of high risk areas vary considerably amongst Queensland's 13 bioregions 
(Table 1). The Brigalow Belt, South East Queensland and the Wet Tropics have the highest numbers of Threatened and Near Threatened plants, which account for around $4-5 \%$ of their total flora. In contrast, the Channel Country, Desert Uplands and Northwest Highlands bioregions have few Threatened and Near Threatened plants, representing $\leq 1 \%$ of their flora.

Although the Brigalow Belt has the largest expanse of high risk areas, they cover only $3.6 \%$ of this large bioregion. In contrast, South East Queensland, New England Tableland and the Wet Tropics have a larger percentage identified as high risk areas. The Channel Country, Gulf Plains, Mitchell Grass Downs, Mulga Lands and Northwest Highlands each have $<1 \%$ of their bioregion classified as a high risk area containing, or potentially containing, protected plants.

Ipomoea antonschmidii plants were found to be perennials that die back to thick tubers in the late dry season (Figure 4). The tubers of some other
Ipomoea species, such as I. polpha, are important food for Aboriginal people (Crase et al., 2010), and this may also be the case of I. antonschmidii, given its large tap roots. During the October 2017 protected plant survey, I. antonschmidii plants had dried leaves and large dry capsules, which is not the best season for a survey, but plants remained observable.

Ipomoea antonschmidii was the only Threatened or Near Threatened species seen during the survey, and it was found in eight of the 17 meanders. A total of 39 I. antonschmidii plants were seen within three regional ecosystems during the protected plant survey (Table 2). None of these plants had been found when doing the broader landscape assessment in 2011, indicating the value of fine-scale surveys using the Guidelines. No I. antonschmidii plants were found in the highly modified non-remnant environment, which mainly consisted of grasses and herbs growing on hard gravel, disturbed soil and tracks.

Table 1. Protected plant high risk areas in each of Queensland's bioregions*

\begin{tabular}{|c|c|c|c|c|}
\hline Bioregion & $\begin{array}{l}\text { Number of } \\
\text { threatened } \\
\text { or NT species } \\
\text { listed under } \\
\text { NCA }^{\dagger}\end{array}$ & $\begin{array}{l}\text { Percentage } \\
\text { threatened or } \\
\text { NT species of } \\
\text { total species } \\
\text { in bioregion }\end{array}$ & $\begin{array}{l}\text { Combined high } \\
\text { risk areas }\left(\mathrm{km}^{2}\right)\end{array}$ & $\begin{array}{c}\text { High risk areas } \\
\text { as percentage of } \\
\text { bioregion area }\end{array}$ \\
\hline Brigalow Belt & 258 & 3.7 & 13,136 & 3.6 \\
\hline Cape York Peninsula & 180 & 4.0 & 5,130 & 2.2 \\
\hline Central Queensland Coast & 54 & 1.4 & 526 & 3.5 \\
\hline Channel Country & 14 & 1.0 & 528 & 0.4 \\
\hline Desert Uplands & 8 & 0.4 & 2,744 & 4.0 \\
\hline Einasleigh Uplands & 166 & 3.3 & 3,742 & 3.2 \\
\hline Gulf Plains & 24 & 1.0 & 506 & 0.2 \\
\hline Mitchell Grass Downs & 38 & 1.9 & 1,554 & 0.6 \\
\hline Mulga Lands & 29 & 1.6 & 599 & 0.3 \\
\hline New England Tableland & 53 & 2.7 & 661 & 8.5 \\
\hline Northwest Highlands & 6 & 0.4 & 290 & 0.4 \\
\hline South East Queensland & 278 & 4.1 & 6,037 & 9.6 \\
\hline Wet Tropics & 284 & 5.1 & 1,501 & 7.5 \\
\hline Total & $942^{*}$ & $10.9 \%$ & $36,952 \mathrm{~km}^{2}$ & $2.1 \%$ \\
\hline
\end{tabular}

* Bioregions defined by Neldner et al. (2019).

† NT refers to Near Threatened species; data are from WetlandInfo (Department of Environment and Science, Queensland, 2017).

* Several Threatened and Near Threatened species occur in multiple bioregions so that the total of 942 NCA listed Threatened or Near Threatened species differs from the sum of species per bioregion. 


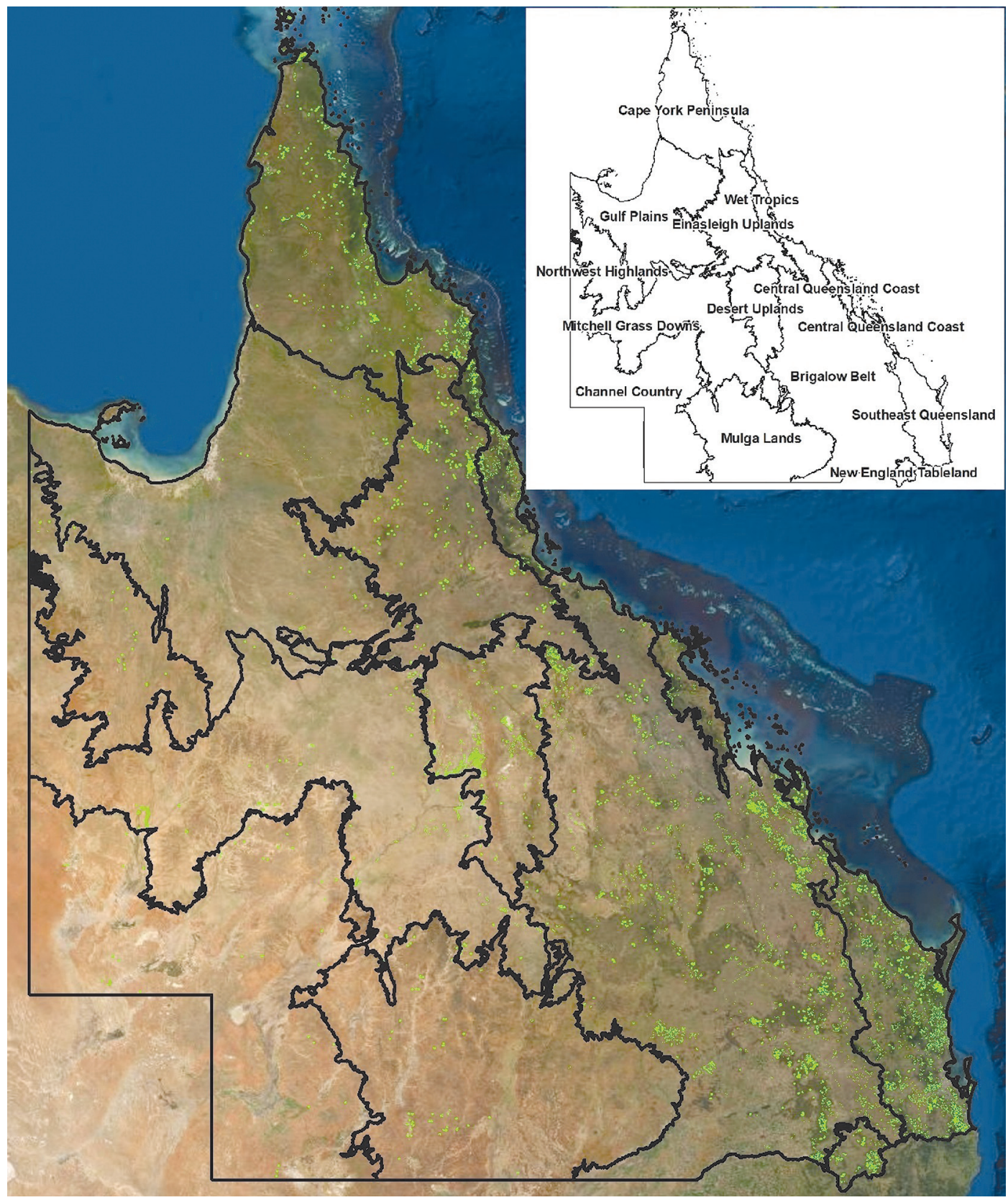

FIGURE 3. High risk areas (light green) within the 13 Bioregions of Queensland (black outline).

Combined, the protected plant survey and the re-survey of seven 2011 I. antonschmidii locations in October 2017 detected a total of 151 I. antonschmidii plants over approximately $10 \mathrm{~km}^{2}$. In locations where I. antonschmidii grows, they averaged one plant per $2.1 \mathrm{~m}^{2}$. Of the total 37 separate locations of I. antonschmidii seen in the 2011 survey, only six fall within a high risk area. The furthest known I. antonschmidii location is $7 \mathrm{~km}$ from a high risk area. 


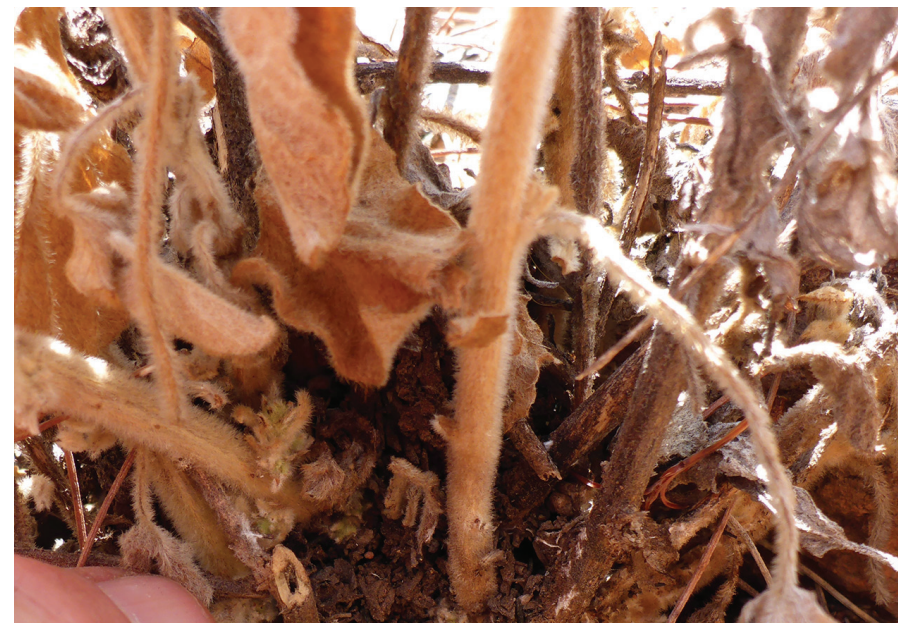

FIGURE 4. Ipomoea antonschmidii thickened stem base, October 2017.

Table 2. The area of each regional ecosystem present within the protected plant survey area, the number of meanders undertaken and numbers of I. antonschmidii plants recorded.

\begin{tabular}{|c|c|c|c|c|}
\hline $\begin{array}{l}\text { Regional } \\
\text { ecosystem }\end{array}$ & Vegetation & $\begin{array}{l}\text { Area covered } \\
\text { (ha) }\end{array}$ & $\begin{array}{l}\text { Number of } \\
\text { meanders }\end{array}$ & $\begin{array}{l}\text { Number of } \\
\text { I. antonschmidii } \\
\text { plants surveyed }\end{array}$ \\
\hline $1.3 .6 \mathrm{a}$ & $\begin{array}{l}\text { Box and ghost gum flats (Eucalyptus } \\
\text { leucophylla; Corymbia aparrerinja) }\end{array}$ & 3.5 & 2 & 25 \\
\hline $1.3 .7 \mathrm{~b}$ & River red gum (E.camaldulensis) & 5.7 & 4 & 1 \\
\hline 1.7 .1 & $\begin{array}{l}\text { Rough-leaved ghost gum (C. aspera) } \\
\text { laterite hillside }\end{array}$ & 1.6 & 1 & 0 \\
\hline 1.7.5 & Lancewood (Acacia shirleyi) & 3.9 & 2 & 0 \\
\hline 1.7 .7 & $\begin{array}{l}\text { Small-fruited bloodwood (C. capricornia) } \\
\text { on silcrete hill }\end{array}$ & 0.4 & 1 & 0 \\
\hline 1.11 .2 & Snappy gum (E. leucophloia) & 5.0 & 2 & 0 \\
\hline 1.11 .8 & $\begin{array}{l}\text { Arid peach and bloodwood (Terminalia } \\
\text { aridicola, } C \text {. terminalis) metamorphic } \\
\text { rocky hillsides }\end{array}$ & 34.7 & 5 & 13 \\
\hline Non-remnant & Cleared, bare ground and plastic covering & 7.0 & $\begin{array}{l}0-\text { visual } \\
\text { inspections only }\end{array}$ & 0 \\
\hline
\end{tabular}

Ipomoea antonschmidii plants were found growing in all but one of the seven separate locations originally observed in April 2011 and re-surveyed in October 2017. The site in which I. antonschmidii plants were not seen in 2017 is an alluvial flat with heavy cattle grazing pressure. Grazing may have removed the above-ground parts, with the plants potentially remaining as dormant tubers.

Although density data was unfortunately not collected in 2011, a total of 112 plants were observed in the seven re-surveyed sites in October 2017 (Table 3). Three of the seven locations where I. antonschmidii were seen in 2011 occur within the high risk area that is a $2 \mathrm{~km}$ radius of the herbarium sample collection site. Three sites are outside the high risk area, and one straddles the margin. A total of 63 I. antonschmidii plants were observed outside the high risk area. 
Table 3. The number of I. antonschmidii plants observed in the seven 2011 locations re-surveyed in 2017, and the regional ecosystem.

\begin{tabular}{|c|c|l|c|}
\hline $\begin{array}{c}\text { 2011 survey } \\
\text { location number }\end{array}$ & $\begin{array}{c}\text { Regional } \\
\text { ecosystem }\end{array}$ & \multicolumn{1}{|c|}{ Vegetation } & $\begin{array}{c}\text { Number of } \\
\text { I. antonschmidii } \\
\text { plants surveyed in 2017 }\end{array}$ \\
\hline 1 & $1.3 .6 \mathrm{a}$ & $\begin{array}{l}\text { Box and ghost gum flats (Eucalyptus leucophylla; } \\
\text { Corymbia aparrerinja) }\end{array}$ & 0 \\
\hline 2 & 1.11 .8 & $\begin{array}{l}\text { Arid peach and bloodwood (Terminalia aridicola, } \\
\text { C.terminalis) metamorphic rocky hillsides }\end{array}$ & 37 \\
\hline 3 & 1.11 .2 & Snappy gum (E. leucophloia) hills & 1 \\
\hline 4 & 1.11 .2 & Snappy gum (E. leucophloia) hills & 26 \\
\hline 5 & 1.3 .5 & $\begin{array}{l}\text { Large-leaved cabbage gum (C. grandifolia) } \\
\text { alluvial flats }\end{array}$ & 37 \\
\hline 6 & 1.3 .5 & $\begin{array}{l}\text { Large-leaved cabbage gum (C. grandifolia) } \\
\text { alluvial flats }\end{array}$ & 5 \\
\hline 7 & 1.3 .6 & $\begin{array}{l}\text { Ghost gum and blood wood (C. aparrerinja; } \\
\text { C.terminalis) alluvial flats }\end{array}$ \\
\hline
\end{tabular}

\section{Discussion}

Protected plant surveys are required under the NCA for proposed disturbances in mapped high risk areas, which currently only cover approximately $2.1 \%$ of Queensland. The one-third reduction in high risk areas in the most recent version of the Guidelines, due to the removal of all protected areas and category $\mathrm{X}$ areas, requires further consideration. It may be worth reinstating protected plant searches in advance of infrastructure clearing in national parks. Some category $\mathrm{X}$ areas contain potential habitat for Threatened or Near Threatened plants, and their complete removal from high risk areas should be reconsidered.

The higher proportion of South East Queensland and Wet Tropics bioregions covered by high risk areas reflects the greater number of rare flora, linked to the broad variety of habitats. It would also be influenced by the high density of botanical surveys and plant samples in the herbarium from those bioregions. Of concern is the low percentage of high risk areas in central and western bioregions, including those with the greatest mining exploration, such as the Brigalow Belt and Northwest Highlands. While this may be a true indication of fewer rare flora, it would also be influenced by lower numbers of botanical surveys and collections. Threatened or Near Threatened plants may be widely scattered in the highly fragmented Brigalow Belt, making them more difficult to detect, so that the high risk areas may underestimate their distribution. The very low number of Threatened or Near Threatened plants in the Channel Country, Desert Uplands and Northwest Highlands suggests less is known about the flora of those bioregions, so that current high risk area maps may not be sufficient to ensure regulation of their rare plants.

In a field-based review of rare flora in the poorly collected Channel Country, Mitchell Grass Downs and Mulga Lands bioregions, Silcock et al. (2014) reported several of their important plant finds were outside targeted survey areas that had been determined on the basis of herbarium specimen and habitat preference knowledge. This highlights the benefit of observations beyond predictable locations. For the extensively cleared Brigalow Belt bioregion, Fensham et al. (2018) considered herbarium specimen records and the extent of clearing for each regional ecosystem, as an approach to identifying Threatened or Near Threatened flora.

The timed meander survey method, preferred by the Guidelines for small- to moderate-sized clearing impact areas (Queensland Government, 2020b), was successful in finding new locations of I. antonschmidii in the Northwest Highlands, which had not been observed in an earlier, broader survey. The Guidelines requirement of searching all habitats was valuable in finding I. antonschmidii, most of which 
were found in different regional ecosystems from that of the original 2011 herbarium sample. Each separate location of I. antonschmidii had sufficiently few plants to be directly counted, rather than sampled using quadrats within transects, both of which are useful options available under the Guidelines.

If the survey was designed using the New South Wales guide for surveying Threatened plants (NSW Department of Planning, Industry and Environment, 2020), $10 \mathrm{~m}$ spaced traverses would have been used to search for this herb. These are estimated by NSW Department of Planning, Industry and Environment (2020) to require 12.5 hours' survey time to cover around 50 ha. This is in comparison to 8.5 hours' active searching in seventeen 30 -minute meanders across 62 ha. These two methods are broadly similar and likely to result in similar detection rates.

Ipomoea antonschmidii plants showed persistence over six years in six out of seven locations, probably as a result of their large tap roots and stem base. The inability to observe plants in one of the 2011 locations may have been due to the high grazing pressure along that alluvial woodland, removing the above-ground biomass of the plants. The plants may have died, or their tubers could remain alive, with the plants more obvious in the wet season.

Based on the IUCN criteria (IUCN, 2019), the current status of Near Threatened is supported for I. antonschmidii. The species has an extent of occurrence of between 20,000 to $40,000 \mathrm{~km}^{2}$, an assumption of $<20,000$ individual plants in total, and may have suffered a potential decline of $>10 \%$, based on the inability to find plants in one of the seven separate locations originally observed in 2011 (i.e. potentially a 14\% decline within 10 years).

The 2017 protected plant survey considered each regional ecosystem as a unique habitat. Under the Guidelines, similar regional ecosystems can be considered the same habitat. If the seven regional ecosystems in this survey were merged into three habitats (i.e. riparian, woodlands on hills, and lancewood), eight rather than 17 meanders could legitimately have been surveyed. It is probable that I. antonschmidii would still have been detected using half the meanders, but plants in some locations may have been missed.

No I. antonschmidii plants were seen growing in the highly modified environment, which was mainly cleared bare earth with scattered grasses and herbs. The Guidelines state highly modified environments, defined as mown, slashed and ploughed areas, impervious surfaces and gravel roads, can be excluded from the required survey area in the $100 \mathrm{~m}$ buffer surrounding proposed disturbance areas. Whether they can be excluded from the survey in the proposed disturbance area is not mentioned in the Guidelines. The first author has found many instances of highly modified environments within high risk areas, such as mown and impervious areas, during over a dozen protected plant surveys using the Guidelines in recent years. We assume all highly modified environments were intended to be removed from high risk areas along with all category $\mathrm{X}$ areas (containing non-remnant regional ecosystems), and the persistence of some is simply due to inaccuracies of mapping at a fine scale. On this basis, it is recommended that highly modified environments encountered during a protected plant survey are excluded from the required survey area. This should apply to the proposed disturbance impact areas, as well as buffers, because they are considerably altered habitats, not simply disturbed regrowth, and divert survey effort from suitable habitats.

In contrast with highly modified environments, surveys within regrowth areas are important for ensuring a thorough assessment because many Threatened or Near Threatened plants regenerate after disturbance. For example, many species of Acacia germinate after fire and mechanical topsoil disturbance, such as the Vulnerable Acacia purpureopetala (PW pers. obs., 2020). Other plants regenerate vegetatively via root suckering, such as the Critically Endangered Zieria gymnocarpa (Williams \& Collins, 2020). Excluding nonremnant areas containing regrowth from surveys creates a risk that protected plants may be missed in advance of proposed disturbances. Version 7.1 of the Guidelines removed all category $\mathrm{X}$ areas, which are particularly extensive in South East Queensland, from the high risk areas across the state. Given the potential habitat for Threatened or Near Threatened plants in some of these category $\mathrm{X}$ areas, it is recommended that a review be undertaken to ensure likely Threatened or Near Threatened plant habitats in non-remnant vegetation are restored to high risk areas. 
In some circumstances, such as clearing for a $10 \mathrm{~m}$ wide, several kilometre long track, the required $100 \mathrm{~m}$ buffer surrounding the impact area is significantly larger than the disturbance footprint. In this example, the required survey area width would be $210 \mathrm{~m}$ for a $10 \mathrm{~m}$ wide disturbance over many kilometres. This potentially distracts the ecologist from focusing on the proposed disturbance and leading to most of the survey in the buffer. It is recommended that the focus of every protected plant survey be concentrated in the planned disturbance impact area, with much less time spent in the buffer area, even where the latter is larger.

The high risk area (i.e. a $2 \mathrm{~km}$ radius from the 2011 herbarium sample collection point) was a useful focal area for searching for the Near Threatened I. antonschmidii. However, of the 151 plants counted in 2017 during both the protected plant survey and the re-survey of seven nearby 2011 survey locations, 63 I. antonschmidii plants were recorded outside the high risk area. That is, $42 \%$ of I. antonschmidii plants would not have been detected using the Guidelines.

Further to this, high risk areas do not cover $84 \%$ of the I. antonschmidii locations seen in 2011. Clearly, the first author of this article should have collected additional specimens of I. antonschmidii during the 2011 survey, or at least submitted sighting records to WildNet, rather than assuming data from the 2011 environmental impact report would be automatically incorporated into WildNet and flora trigger maps. With the current focus of protected plant surveys on buffers around specimens and sighting records, it is important for botanists and ecologists to be aware of the need for replicating herbarium collections and/or sightings data over the scale of only a kilometre to improve high risk area maps.

Searches for Threatened or Near Threatened flora are also undertaken across the state as part of environmental impact assessments for large developments. These assessments can be quite broad in scope and do not necessarily use the Guidelines to meet NCA requirements, because clearing activities may be many years away. The protected plant survey reports have a two-year expiry date. Therefore, to some extent, protected plant surveys are considered thorough pre-clearing surveys, undertaken not long before clearing is proposed.
The protected plant legislation has inadvertently limited plant collection opportunities. This is because of the requirement for landowner approval for collecting plant samples and the view of many that having a high risk area on their property could impact their management options. A recent court case is a documented example of this concern (Land Court of Queensland, 2020). While herbariumbased specimens provide the highest quality data, vetted sighting records on WildNet could greatly improve our knowledge of Threatened or Near Threatened plant distributions. For example, the state-based NSW BioNet records are used in New South Wales to determine rare flora survey requirements (NSW Department of Planning, Industry and Environment, 2020; J. Hunter pers. comm., 7 July 2021). However, it remains critical that only highquality records are used to retain confidence in the high risk mapping. Currently, not all rare plant sightings on WildNet are used in determining high risk areas. For example, a few WildNet records of the Near Threatened Cerbera dumicola in the Brigalow Belt are not represented in high risk areas. These are recorded in non-remnant areas immediately adjacent to remnant woodlands, and it is possible the species grows in the remnant vegetation, therefore warranting a high risk area.

The purpose of mapped high risk areas is to indicate there is an elevated danger of damaging a protected plant during a proposed clearing, because a particular species is known to occur, or likely to occur in close proximity. The effectiveness of protected plant surveys would therefore be improved if the names of listed Threatened or Near Threatened species responsible for a high risk area (i.e. the species at high risk of being disturbed) are supplied with the trigger map to approved suitably qualified persons. While it is essential that all potential Threatened or Near Threatened flora in a district are considered during surveys, given our imperfect knowledge of plant distributions, suitably qualified persons undertaking pre-clearing surveys should be made aware of the species at greatest risk. Knowing which species triggered the high risk area will help ensure appropriate survey timing and the search image for the appropriate plant(s). For example, it would be valuable for the plant surveyor to know whether the high risk area has been triggered by an epiphytic orchid, a forb 
or a tree. Currently, the ecologist must make an educated guess, with records of some plant groups (e.g. orchids and cycads) generalised to $0.1^{\circ}$ (i.e. $11 \mathrm{~km}$ ) of their collection location, yet orchids make up $11 \%$ of Queensland's Threatened or Near Threatened flora. Knowing which Threatened or Near Threatened plant to target is even more difficult where the high risk area has been expanded beyond a $2 \mathrm{~km}$ radius of a sighting record on the basis of modelled potential habitat. Indeed, the habitat modelling of Threatened or Near Threatened flora distributions used in determining high risk areas requires testing and potential refinement.

A clear pathway is needed for emerging plant ecologists to become a "suitably qualified person" to lead a protected plant survey under the Guidelines. Currently, the criteria for a suitably qualified person are heavily weighted towards academia (i.e. "a relevant qualification from a recognised institution" and/or published papers), and the field experience component only allocates points for people who already have experience at leading multiple rare flora surveys within the last 2 years and/or have collected plant samples that are incorporated into the herbarium. It is recommended an additional criterion be added that credits experience assisting in protected plant surveys. For example, "the person has assisted a suitably qualified person in protected plant surveys annually for at least three years, with 5 points allocated per survey, to a maximum of 60 points".

In conclusion, we found the Guidelines provide a useful approach for surveying Threatened or Near Threatened plants. Some refinements are suggested which could improve their effectiveness as a search method. Currently, the high risk areas underestimate the extent of Threatened or Near Threatened flora. This will improve with ongoing collections and sighting records, which should be undertaken at the scale of only a kilometre between observations.

\section{Acknowledgements}

We are grateful to Joel Stibbard for assistance with the April 2011 survey, to the Queensland Department of Natural Resources, Mines and Energy for funding the 2017 survey, and the landholder for granting permission to access the property. Two anonymous reviewers and the journal's editor, Julien Louys, provided thought-provoking, valuable comments on an earlier draft. We are also grateful for discussions with a range of people about the Queensland protected plant Guidelines, and NSW flora surveys, including Loren Appleby, Gordon Guymer, Dan Hede, John Hunter, Lincoln Smith, David Stanton and Kerry Walsh.

\section{Literature Cited}

AVH. (2021). Australasian Virtual Herbarium. Council of Heads of Australasian Herbaria. https://avh.ala. org.au/occurrences/search?taxa=Ipomoea+antonschmidii+\#tab_mapView.

Brown, G. K., \& Bostock, P. D. (2020). Introduction to the Census of the Queensland Flora 2020. Queensland Department of Environment and Science.

Crase, B., Duguid, A., Pengart, R. N., Jakamarra, P. W., Angal, L. P., Pengart, M. S., \& Kemarr, A. W. (2010). Distribution and conservation status of the giant sweet potato, a rare Aboriginal food plant from Central Australia. Northern Territory Naturalist, 22, 17-30.

Department of Environment and Science, Queensland. (2017). About us. WetlandInfo. Retrieved 28 August 2021, from https://wetlandinfo.des.qld.gov.au/wetlands/about-us/

ESRI. (2009). ArcMap Version 9.3.1. ESRI Australia.

Fensham, R. J., Laffineur, B., \& Silcock, J. L. (2018). In the wake of bulldozers: Identifying threatened species in a habitat decimated by rapid clearance. Biological Conservation, 219, 28-34. https://doi. org/10.1016/j.biocon.2017.12.008

IUCN. (2019). Guidelines for Using the IUCN Red List Categories and Criteria (Version 14). Prepared by the Standards and Petitions Committee.

Johnson, R. W. (1986). Four new species of Ipomoea L. (Convolvulaceae) from Australia. Austrobaileya, $1,217-223$. 
Keith, D. A. (2000). Sampling designs, field techniques and analytical methods for systematic plant population surveys. Ecological Management \& Restoration, 1, 125-139. https://doi.org/10.1046/j. 1442-8903.2000.00034.x

Land Court of Queensland. (2020). Conway \& Ors v Australia Pacific LNG CSG Transmissions Pty Ltd \& Anor [2020] QLC 26.

Neldner, V. J., Wilson, B. A., Dillewaard, H. A., Ryan, T. S., Butler, D. W., McDonald, W. J. F., Addicott, E. P., \& Appelman, C. N. (2019). Methodology for survey and mapping of regional ecosystems and vegetation communities in Queensland (Version 5.0. Updated March 2019). Queensland Herbarium, Queensland Department of Environment and Science, Brisbane.

NSW Department of Planning, Industry and Environment. (2020). Surveying threatened plants and their habitats NSW survey guide for the Biodiversity Assessment Method. NSW Environment, Energy and Science.

Queensland Government. (2020a). Nature Conservation (Plants) Regulation 2020 Protected Plants Assessment Guidelines.

Queensland Government. (2020b). Flora Survey Guidelines - Protected Plants (Version 2.01). https:// www.qld.gov.au/__data/assets/pdf_file/0028/99901/gl-wl-pp-flora-survey.pdf

Silcock, J. L., Healy, A. J., \& Fensham, R. J. (2014). Lost in time and space: re-assessment of conservation status in an arid-zone flora through targeted field survey. Australian Journal of Botany, 62, 674-688. https://doi.org/10.1071/bt14279

Williams, P., \& Collins, E. (2020). Vegetation monitoring in Brisbane City Council Conservation Reserves. Report to the Brisbane City Council.

\section{Author Profiles}

Paul Williams is a plant ecologist interested in land management, especially the use of regular lowintensity burning under good soil moisture conditions to maintain vegetation health; and in surveys and research that improve our management of threatened species.

Bree Clouten is an environmental scientist with interests in sustainable natural resource regulation and how ecological research can improve land management practices and outcomes. 